Teologia i Moralność, volumen 13(2018), numer 2(24)

doi: 10.14746/tim.2018.24.2.3

ORCID: 0000-0002-2498-5081

\author{
JANUSZ NAWROT \\ Uniwersytet im. Adama Mickiewicza w Poznaniu \\ Wydział Teologiczny
}

\title{
Biblijne fundamenty encykliki Humanae vitae
}

Encyklika, o której mowa w tytule niniejszego artykułu, napisana została w roku 1968, roku doniosłych przemian, zwłaszcza na kontynencie europejskim, rewolucji młodzieżowej, powstawania tzw. „dzieci kwiatów”, ruchów hippisowskich, czyli tego, co dziś nosi nazwę kontrkultury kontestacyjnej. Ideą przewodnią całego ruchu było proklamowanie powszechnego buntu młodych przeciwko światu dorosłych i temu, co sobą reprezentował, przede wszystkim uznanym dotąd społecznie instytucjom: rodzinie, Kościołowi, szkole, stosunkom panującym w pracy, potędze pieniądza, konieczności służenia w wojsku, przeciw wojnie, normom moralnym, jakimkolwiek konwencjom ubioru, a na koniec także własności prywatnej. Kontrkultura ta odrzucała zwłaszcza normy społeczne oparte na kapitalizmie, zatem konsumpcji, rywalizacji i materializmie. Bardzo szybko przestał obowiązywać kanon zachowań społecznych i moralnych, a wszystko pozostawiono wolnej woli człowieka, w tym prawo wyboru własnego sposobu życia, używania antykoncepcji, prawo do aborcji ${ }^{1}$. W tym kontekście pojawił się dokument, który mógł być odczytany jako klasyczna próba dominacji „starych nad młodymi”, Kościoła nad społeczeństwem, instytucji nad wolnością, zakazów nad swobodą itd. Paweł VI miał świadomość dokonujących się zmian, jak to wyniknie z brzmienia encykliki oraz sposobu argumentacji, opartej na rozumie i spodziewanych korzyściach dla życia rodzinnego. Nawet pośród wielu episkopatów krajów chrześcijań-

${ }^{1}$ Jedną z najnowszych pozycji opracowujących ten temat jest praca zbiorowa pod redakcją Roberta Gilde'a, Jamesa Marka oraz Anette Warring, pt. Europe's 1968: Voices of Revolt, Oxford 2017 oraz specjalne wydanie The Editors of TIME, zatytułowane: TIME 1968: The Year That Shaped A Generation, London 2018. 
skich jego słowa nie spotkały się z należytym zrozumieniem i przyjaznym przyjęciem $^{2}$.

Próbując przeanalizować ten ważny i doniosły także dla czasów współczesnych dokument papieski pod kątem jego odniesień do tekstu natchnionego, zauważyć należy na samym początku, że explicite takowych jest stosunkowo niewiele i wszystkie odnoszą się jedynie do tekstów nowotestamentowych ${ }^{3}$. Prawdą jest, że tekst encykliki również nie jest obszerny, zamyka się w 31 punktach $^{4}$. Na próżno natomiast szukać wyraźnych odniesień do jakże ważnych wersetów Starego Testamentu, już na samym początku historii ludzkości akcentujących fundamenty małżeństwa i rodziny. Po drugie ważne jest to, że papież nie dokonuje egzegezy przytaczanych cytatów, kontentując się jedynie przytoczeniem ich na potwierdzenie prezentowanych przez siebie tez i myśli. Artykuł jest próbą szerokiego nakreślenia biblijnego fundamentu twierdzeń zawartych w dokumencie papieskim tam, gdzie odniesienie do ksiąg Pisma Świętego wydaje się szczególnie doniosłe i wartościowe. Pozwoli to ukazać sens zakotwiczenia tekstu encykliki w prawdach wynikających z nieomylnego słowa Bożego, co w świetle nauczania Kościoła miało niemały wpływ na uzasadnienie jej nienaruszalności w kwestiach moralnych tak ważnych, jak szeroko pojmowana ludzka płciowość. W niniejszym artykule ograniczymy się do podania tylko tych cytatów, które odnoszą się do dogmatycznych podstaw opisywanych przez papieża zagadnień.

Jeśli na wstępie spróbować odpowiedzieć na pytanie, dlaczego relatywnie tak niewiele wersetów ksiąg natchnionych znalazło swe miejsce w tekście encykliki, powodu głównego można się chyba dopatrywać w obowiązującym jeszcze kilka lat po Soborze Watykańskim II stylu pisania dokumentów papieskich, w których wyraźnie dominowało cytowanie przede wszystkim szeroko pojmowanego magisterium Kościoła. Warto zauważyć, że jeśli odniesień biblijnych można się doszukać jedynie w 18 przypisach, to cytowań oficjalnych orzeczeń soborowych, Katechizmu Kościoła katolickiego, Kodeksu prawa kanonicznego, przemówień, encyklik, listów papieskich, dzieł teologicznych oraz innych zapisów Actorum Apostolicae Sedis jest niemal 60. W życie

${ }^{2}$ Dzisiejsze wyzwania wobec moralności wyznaczonej przez encyklikę Humanae vitae ukazuje m.in. Stanley 2013, s. 15-20.

${ }^{3}$ Oto one w kolejności występowania: Mt 28,18-19; 7,21; 1 J 4,8; Ef 3,15; Rz 3,8; Łk 2,34; Rz 8; Mt 11,30; Mt 7,14; Hbr 12,11; Tt 2,12; 1 Kor 7,31; Rz 5,5; Ef 5,25.28-29.32-33; 1 Kor 1,10 oraz J 3,17. Ze względów ograniczeń ilości materiału autor artykułu zmuszony zostanie do pominięcia teologii całego tekstu Rz 8, stanowczo zbyt rozległego na objętość artykułu naukowego. Dość powiedzieć, że tekst ów został zacytowany jako eksplikacja konieczności życia według praw Ducha, nie według ciała, co jest konieczne dla poprawnego zrozumienia intencji, jaką kierował się papież, wydając całą encyklikę.

${ }^{4}$ Obecnie dostępne różne układy tekstu dokumentu podają także różne liczby stronic, dlatego lepiej jest definiować obszerność dzieła właśnie liczbą punktów składających się na nie. 
wchodziła dopiero Konstytucja Dei Verbum, kształtująca odnowioną mentalność biblijną, której magisterium ma być sługą, jak to ukazuje stosowny zapis dokumentu soborowego:

Zadanie autentycznej interpretacji słowa Bożego, spisanego czy przekazanego przez Tradycję, powierzone zostało samemu tylko żywemu Urzędowi Nauczycielskiemu Kościoła, który autorytatywnie działa w imieniu Jezusa Chrystusa. Urząd ten Nauczycielski nie jest ponad słowem Bożym, lecz jemu służy, nauczając tylko tego, co zostało przekazane. $Z$ rozkazu Bożego i przy pomocy Ducha Świętego słucha on pobożnie słowa Bożego, święcie go strzeże i wiernie wyjaśnia. I wszystko, co podaje do wierzenia jako objawione przez Boga, czerpie $\mathrm{z}$ tego jednego depozytu wiary (KO 10).

W encyklice daje się jeszcze zauważyć owo wszechwładne panowanie prawa i dogmatyki katolickiej nad studium tekstów biblijnych, które nie powinny jedynie służyć potwierdzaniu suchego i scholastycznego wykładania prawd wiary, lecz stanowić ich źródło, z którego wypływa wszystko, czym Kościół się karmi i czego naucza. Nie można jednak pominąć faktu, że - jak zaznacza konstytucja - oprócz ksiąg natchnionych równorzędnym źródłem nauczania w Kościele jest Tradycja, na którą składają się przecież wszystkie dokumenty, które Paweł VI konkretnie w swej encyklice przytoczył, ponieważ „Kościół osiąga pewność swoją co do wszystkich spraw objawionych nie przez samo Pismo święte (KO 9), zaś w swej nauce [...] uwiecznia i przekazuje kolejnym pokoleniom to wszystko, czym on jest i to wszystko, w co wierzy" (KO 8).

Względnie nieduża liczba wersetów ksiąg świętych pozwala nakreślić pewien obraz sposobu i treści cytowanych odniesień, a ich przemieszanie pozwala wysnuć już pierwszy wniosek, że wszystkie traktowane są w nauczaniu papieskim z równą powagą.

Na koniec dodać należy uwagę interpretacyjną dla czytelników co do sposobu przywoływania ksiąg świętych. Autor zastosował sigla Septuaginty tam, gdzie korzysta $\mathrm{z}$ tekstu greckiego. Pojawią się więc następujące sigla, pisane kursywą: 1 Bas $=1 \mathrm{Sm} ; 2$ Bas $=2 \mathrm{Sm} ; 3$ Bas $=1 \mathrm{Krl} ; 4$ Bas $=2 \mathrm{Krl} ; 1$ Par = $1 \mathrm{Krn} ; 2$ Par $=2 \mathrm{Krn} ; P_{S}=$ grecka wersja Księgi Psalmów z odpowiednią tam ich numeracją; Ier = grecka wersja Księgi Jeremiasza z odpowiednią numeracją rozdziałów. Pozostałe księgi wymieniane są według klucza hebrajskiego.

\section{Miłość Boga i Jego powszechne ojcostwo}

W tym punkcie należy zacytować jedynie dwa pierwsze odniesienia do Biblii, występujące w tekście dokumentu, ponieważ funkcjonują jako potwier- 
dzenie fundamentalnej zasady działania miłości małżeńskiej i nie mają odniesienia do konkretnych postaw ludzkich, jak to będzie miało miejsce w innych przypadkach, gdy przez autora wyraźnie powoływane są wersety natchnione. Papież pisze zatem w punkcie 8: „Miłość małżeńska najlepiej objawia nam swą prawdziwą naturę i godność dopiero wtedy, gdy rozważymy, że początek swój czerpie ona - jakby z najwyższego źródła - z Boga, który jest Miłością (1 J 4,8) i Ojcem, «od którego bierze swe imię wszelkie ojcostwo na niebie i na ziemi»»" $($ Ef 3,15) .

Pierwszy z cytowanych wersetów odgrywa rolę uzasadnienia charakteru i wielkości tej najbardziej fundamentalnej i koniecznej ze wszystkich relacji ludzkich, jaką jest właśnie miłość ${ }^{6}$. Papież akcentuje zarówno nierozerwalny związek między Bogiem jako miłością ${ }^{7}$ a człowiekiem ${ }^{8}$, który zostaje $\mathrm{w}$ nią wyposażony, otwierając się na drugiego, jak i wynikającą z tego powinność moralną: relacja osoby z równą sobie istotą powinna być wypełniona miłością. Uprzywilejowanym zaś środowiskiem urzeczywistnienia jej w każdej formie jest małżeństwo. Aby uzasadnić tę tezę, przywołany został ów podstawowy związek mężczyzny i kobiety zarówno jako akt ustanowiony przez Boga, jak i akt podniesiony do godności sakramentu przez Chrystusa. Co jednak warto tu szczególnie podkreślić, to fakt, że miłość Boża objawia się wyłącznie w relacji bytów nierównych sobie, jako forma boskiej aktywności obdarzającej, lecz niebiorącej nic w zamian. Natomiast miłość małżeńska ukazuje swe zalety w związku bytów równych sobie, zarówno obdarzając, jak i przyjmując dar. $\mathrm{Z}$ tej racji encyklika wartościowo wpływa na interpretację tekstu biblijnego, gdzie Bóg jawi się wpierw jako absolutna pełnia wszelkich darów dla człowieka, lecz także jako Twórca i Dawca ludzkiej umiejętności dawania i przyjmowania, chociaż sam od swych stworzeń nie przyjmuje niczego, aby ubogacić siebie. W takim sensie nie jest błędem egzegetycznym rozdzielenie obu części wersetu i pominięcie pierwszej, która w biblijnej wersji w całości brzmi tak: „Kto nie miłuje, nie zna Boga, bo Bóg jest miłością” (1 J 4,8). Co więcej, małżeńska rzeczywistość miłości niejako uzupełnia rozumienie części pierwszej

${ }^{5}$ Tłumaczenie polskie tekstu dokumentu za: http://npr.pl//index.php/content/view/169/42/ [dostęp: 14.02.2018].

${ }^{6}$ Biblijną teologię miłości w myśl omawianego tekstu prezentuje m.in. Haręzga 2007, s. 72-74.

${ }^{7}$ Werset akcentuje mocno miłość jako rzeczownik. Autor nie pisze, że „Bóg kocha/miłuje”, lecz że ,jest miłością’”. Oznacza to, że miłość stanowi istotę Bożego istnienia i nie można jej pojmować jedynie jako jedną z funkcji tegoż istnienia. Dzięki niej jest ono nakierowane zawsze na relację wpierw między samymi Osobami Boskimi, potem między Stwórcą a stworzeniem (por. Boring, Craddock 2009, s. 749).

${ }^{8}$ Egzegeci stwierdzają, że w kontekście w. 7-10 w cytowanym sformułowaniu nie chodzi o spekulacje dotyczące natury samego Boga, lecz odwołanie się do Jego aktywności w świecie ludzkim, ponieważ „miłość jest aktywnością osobową, nie abstrakcyjną cechą” (por. Rensberger 1997, s. 117). 
tekstu biblijnego: brak miłości w człowieku czyni go niezdolnym zarówno do obdarzania, jak i do przyjmowania daru od bliźniego na wszystkich poziomach ludzkiego funkcjonowania. W myśl analizowanego wersetu dotyczy to trwania we wspólnocie wierzących. Tylko bowiem wówczas Chrystus jako Bóg obdarza uczniów swą miłością. Wszelkie próby secesji i rozbijania wspólnoty z definicji zamykają na Jego miłość (por. Kruse 2000, s. 17). Tym bardziej więc musi dotyczyć to wspólnoty miłości między mężczyzną a kobietą, fundowaną nie na własnych, czysto ludzkich możliwościach, lecz na ożywiającej miłości Bożej ${ }^{9}$. Zanegowanie tej wspólnoty oznacza odrzucenie miłości Tego, który stoi u jej fundamentów. Z kolei poznanie istnienia i aktywności miłości Bożej staje się możliwe właśnie dlatego, że człowiek potrafi kochać drugiego, zatem jego własna, ludzka miłość ma wartość dowodu na istnienie w nim miłości Bożej. Jest to najmocniejszy argument na rzecz miłości Boga skierowanej ku człowiekowi obok posłania Jego Syna na świat w ludzkiej, widzialnej naturze dla zbawienia wszystkich ludzi (w. 10; por. Stott 1995, s. 165-166). W myśl tekstu encykliki do kształtowania miłości w człowieku miłość Boża jest bezwarunkowo konieczna, ponieważ związek obu jest ontologicznie nierozerwalny ${ }^{10}$, choć człowiek może go zanegować swą postawą życiową, a nawet się mu sprzeniewierzyć.

Dalej, ważne z punktu widzenia dogmatyki katolickiej jest połączenie miłości małżeńskiej z Bożym ojcostwem, gdy papież obok miłości Boga odnosi się do tego właśnie Jego atrybutu. Ojciec Święty, nawiązując do Biblii, niewątpliwie chce wyrazić łączność między miłością małżonków a płodnością ich związku, co najpełniej przejawia się w jedności i rodzicielstwie ${ }^{11}$. Co jednak ma na myśli autor Listu do Efezjan, pisząc w 3,15 o ojcostwie Boga? Bóg sam jest nie tylko Ojcem, lecz Tym, od którego wszelkie istniejące żywe byty czerpią natchnienie do działania. Niektórzy egzegeci zwracają uwagę, że nie cho-

${ }^{9}$ Człowiek wchłania niejako w siebie to, co ze swej natury Bóg mu ofiaruje: miłość staje się cząstką samego Boga w człowieku (por. Johnson 1993, s. 102).

${ }^{10}$ Jezus daje temu świadectwo w J 15,5 oczywiście przy założeniu właśnie ontologicznym, nie jedynie $\mathrm{w}$ wyniku uprzedniej wiary w Niego. Komentatorzy, opierając się na kontekście w. 4-6, zakładają bez dyskusji, że mowa Jezusa odnosi się do Jego uczniów (por. m.in. Mędala 2008, s. 116). Nie poruszają jednak kwestii, czy to oddziaływanie Jezusa dotyczy wszystkich ludzi, także niewierzących w Niego. Odrzucić natomiast trzeba interpretację tekstu wiodącą w kierunku negacji jakiejkolwiek niemożności działania przez człowieka poza Jezusem. Jego słowa bardziej odnoszą się do pozytywnych skutków Jego aktywności w uczniach (por. X. Léon-Dufour 1993, s. 169).

${ }^{11}$ Najwyraźniej tezę tę przedstawi w punkcie 12 swego dokumentu: „[...] stosunek małżeński z najgłębszej swojej istoty, łącząc najściślejszą więzią męża i żonę, jednocześnie czyni ich zdolnymi do zrodzenia nowego życia, zgodnie z prawami zawartymi w samej naturze mężczyzny i kobiety. Jeżeli zatem zostaną zachowane te dwa istotne elementy stosunku małżeńskiego, a więc oznaczanie jedności i rodzicielstwa, to wtedy zatrzymuje on w pełni swoje znaczenie wzajemnej i prawdziwej miłości oraz swoje odniesienie do bardzo wzniosłego zadania, do którego człowiek zostaje powołany - a mianowicie do rodzicielstwa". 
dzi o wszelkie ojcostwo na ziemi jako odblask niebiańskiego ojcostwa Boga, lecz o dziecięctwo Boże wiernych, pozostających we wspólnocie Kościoła ${ }^{12}$. Dlatego chodzi nie tyle o „ojcostwo" jako takie, ile o istnienie konkretnej, każdej, ludzkiej rodziny. Grecki termin patria oznacza 'pochodzenie', 'rodowód zwłaszcza ze strony ojca'13, co w konsekwencji przeradza się właśnie w 'rodzinę' lub - szerzej - 'pokolenie', 'szczep', 'ród', 'potomstwo' ${ }^{14}$. Chodzi zatem nie tyle o „ojcostwo" jako cechę samego Boga, ile wszystko (pasa) to, co od Niego bierze początek, wszelkie Jego stworzenie, które On powołał do istnienia i życia ${ }^{15}$. Jeśli zaś spojrzeć na zagadnienie od strony stworzenia, każde doświadczenie własnego ojcostwa ma swe źródło w Bogu jako Ojcu. Każdy wierzący człowiek, doświadczając jakiejkolwiek funkcji rodzicielskiej, czyni to na sposób Boży i do Niego ją odnosi (por. Foulkes 1989, s. 109). W ten sposób Bóg jako Ojciec, Stworzyciel wszelkich bytów na niebie i na ziemi (Ef 3,9), nazywa je po imieniu. Na podobieństwo rodziców dających imię swemu dziecku rozpoznaje w ten sposób i uznaje, jako własne, całe stworzenie w niebie i na ziemi, definiuje ich istotę i sposób bycia, biorąc odpowiedzialność za ich funkcjonowanie i rozwój (por. Fowl 2012, s. 165). W ten sposób daje się poznać jako Bóg żyjący i wciąż działający pośród swego stworzenia, jako zarówno kochający Ojciec, jak i panujący nad wszelkim życiem Władca ${ }^{16}$. Tak samo rodzice, wychodząc od miłości wzajemnej, mają powoływać do życia swe dzieci, czuć się za nie odpowiedziali i kierować umiejętnie ich rozwojem.

\section{Mandat misyjny Kościoła}

Jedynym ${ }^{17}$ przykładem zastosowania explicite jest $\mathrm{w}$ omawianym dokumencie papieskim ewangeliczny zapis Mt 28,18-19 skomentowany treściowo w sposób następujący w punkcie 4: ,[...] Jezus Chrystus czyniąc Piotra

${ }^{12} \mathrm{~W}$ ten sposób m.in. Langkammer 2001, s. 73.

${ }^{13}$ O czym wspomina np. Herodot, Dzieje III, 75 (por. Bailly 1963, s. 1499).

${ }^{14}$ Por. w liczbie pojedynczej, jak w omawianym tekście: Wj 6,15.26; Lb 1,47; 3,24; 18,1; 25,14-15; 36,4.7; Pwt 18,8; 29,17; Joz 22,14; 2 Bas 14,7; 3 Bas 4,6; 1 Par 5,7; 6,39.55; 11,25; 23,11; 24,6; 2 Par 35,5; 2 Ezd 2,59; Est 4,17m; 9,27; Jdt 8,18; Tb 5,12.14; Jr 2,4; 3,14; 25,9; Łk 2,4.

${ }^{15}$ Warto w tym miejscu przypomnieć dwa teksty starotestamentowe, zawierające tę samą ideę pochodzenia od wspólnego przodka wszystkich wierzących, mianowicie Rdz 12,3 oraz 22,18, oba odnoszące się do Abrahama, który stanie się źródłem błogosławieństwa dla swych potomków, o czym wspomina Piotr w swej mowie w Dz 3,25.

${ }^{16}$ Co wcześni chrześcijanie wyznawali od samego początku (Dz 4,24; por. także Hoehner 2002, s. 474-476).

${ }^{17}$ Znaczna część tekstów biblijnych została zastosowana w papieskim dokumencie w sposób aluzyjny. Obecnie skupiamy się jedynie na tym, którego pojawienie się jest typowo informacyjne i nie zmierza do egzegezy. Pozostałe cytaty umiejscowione zostały w punktach wskazujących na ich ważniejszą, niż informacyjna, rolę. 
i Apostołów uczestnikami swojej boskiej władzy i posyłając ich, aby nauczali wszystkie narody Jego przykazań [...]".

Zdanie to zostało zawarte w części encykliki zwracającej czytelnikowi uwagę na konieczność podporządkowania się nauczaniu magisterium Kościoła oraz zaakceptowania jego prawa do formułowania tez i wynikających z nich wniosków moralnych. Papież przypomina stanowczo, że autentyczna interpretacja prawa naturalnego w świetle Bożego objawienia leży w wyłącznej kompetencji Urzędu Nauczycielskiego, o czym wielokrotnie przypominali poprzednicy Pawła VI na papieskim tronie. Tekst Mateusza został wykorzystany do potwierdzenia tradycji nauczania magisterium jako instancji autorytatywnej i zobowiązującej do posłuszeństwa wierze ${ }^{18}$. Analiza cytatu biblijnego rozszerza jurysdykcję apostolską o autentyczne strzeżenie depozytu wiary oraz jego wykładania, zwłaszcza w obrębie całego prawa moralnego, ukazanego nie tylko na kartach Ewangelii, ale także jako prawa naturalnego. Jest ono bowiem tak samo, jak objawione w Biblii, wyrazem woli Bożej, a jego przestrzeganie przez wszystkich ludzi stanowi conditio sine qua non ich zbawienia. Opierając się na tej prawdzie, Kościół podjął się obu wyżej wskazanych ról stróża skarbu wiary oraz jej nauczyciela, czemu służy formułowanie odpowiednich dokumentów - w kontekście encykliki zwłaszcza tych, które dotykały problematyki małżeństwa, należytego korzystania z praw małżeńskich oraz przypominały małżonkom ich obowiązki. Ostatecznie nie można pominąć faktu, że ponieważ prezentowany tekst biblijny stanowi najważniejsze z ogólnych przesłań Jezusa do uczniów, podpieranie nim autorytetu nauczającego Kościoła oznacza świadomość najwyższej odpowiedzialności za otrzymany w spadku skarb wiary ${ }^{19}$. Tak zawsze dzieje się zwłaszcza wówczas, gdy mamy do czynienia $\mathrm{z}$ tekstami moralnymi dotyczącymi zachowań indywidualnych, lecz o wielkim znaczeniu społecznym.

Całość ostatniej mowy Jezusa do uczniów, zanotowanej przez Mateusza, składa się z 3, nie 2 wersetów, przy czym w w. 20 widnieje nakaz uczenia, by wszyscy, którzy zaznajomią się z prawdami wiary komunikowanymi przez uczniów, dostosowali swe postępowanie do ich wymagań. Wydawałoby się, że werset ów powinien w sposób naturalny zostać dołączony do całości mowy Jezusa. Papież jednak zdecydował się na podanie jedynie tych słów, które do-

${ }^{18}$ Tak działo się już od najwcześniejszej tradycji Kościoła, notowanej jeszcze w odtworzonym, hebrajskim tekście Ewangelii, gdzie nakaz nauczania nowych adeptów wiary formułowany jest tak samo, jak powinność uczenia się Tory, czyli podstawy wiary Izraela (por. Goniszewski 2015, s. 16).

19 „Pomoc rodzinie w wychowaniu niesie przede wszystkim Kościół, który ma prawo do wychowania, ponieważ jego charakter jest nadprzyrodzony, zaspokajający naturalne dążenie człowieka do świętości. Kościołowi przysługuje wyłączne prawo do publicznego nauczania prawd religijnych. Ma też prawo nauczania w innych dziedzinach wiedzy i zakładania szkół wszystkich stopni” (por. Struzik 2010, s. 117). 
tyczą prawa Kościoła do interpretacji i nauczania wiernych tego, co w depozycie otrzymał od swego Założyciela, i odłożył chwilowo kwestię posłuszeństwa. Wydaje się, że był to zabieg o tyle przemyślany i wartościowy, że owego posłuszeństwa, jako najwyższy pasterz Kościoła, będzie oczekiwał po przedstawieniu treści encykliki, wyjaśnieniu spraw w niej zawartych i podaniu logicznej i właściwej do przyjęcia argumentacji. Nie chciał bowiem zapewne domagać się tego posłuszeństwa od razu i jedynie na podstawie tekstu biblijnego ${ }^{20}$.

W jakim kontekście historyczno-teologicznym padają znane słowa Jezusowego posłania misyjnego? Wydarzenie ma miejsce już po zmartwychwstaniu Jezusa, w Galilei, gdzie rozpoczęła się misja Jego uczniów. Ważna wydaje się wzmianka (w. 17) o niepewności części apostołów ${ }^{21}$, ponieważ to w jej kontekście Jezus wypowiada swój nakaz misyjny w tonie uroczystym i apodyktycznym, bez udowadniania prawdziwości stwierdzenia. Ludzkie wątpliwości nie mogą zatem przesłonić wagi otrzymanego nakazu. Literacka budowa perykopy jest jasna i konsekwentna:

w. 18: wszelka władza na niebie i ziemi dla Jezusa ${ }^{22}$;

w. 19: misja dla apostołów czynienia uczniami ${ }^{23}$ połączona z ochrzczeniem w imię Ojca, Syna i Ducha Świętego;

w. 20a: nakaz zachowywania nauki apostolskiej;

w. 20b: zapewnienie o wiecznej i stałej obecności Jezusa przy uczniach.

${ }^{20}$ Podejmowanie osądu właściwego osobie stanowi jeden z kluczowych punktów poczucia jej godności, o czym przekonywał K. Wojtyła w dwóch swych dziełach: Osoba i czyn oraz Miłość i odpowiedzialność. Skrótowe omówienie personalistycznej filozofii człowieka w obszarze postępowania moralnego u K. Wojtyły por. m.in. Biesaga 2011, s. 328-330. Dziełem pomocnym dla rozważań o relacji doświadczanej prawdy oraz właściwego osądu etycznego, jaki z niego wypływa, por. m.in. Krajewski 2006.

${ }^{21}$ Występujący jeszcze tylko w Mt 14,31 czasownik distadzō oznacza 'wątpię", "jestem w niepewności” (por. Bailly 1963, s. 521). Stąd w kontekście Ewangelii chodzi o postawę niezdecydowania, wątpliwości, rozterki czy wahania. Dopełniający ów czasownik w 14,31 rzeczownik oligopistos wyraźnie wskazuje na słabość ludzkiej wiary w sytuacji, w której wiarę tę należało okazać ze względu na bliskość Boga lub Jego oczywiste działanie pośród ludzi (Mt 6,30, 8,26; 16,8). Nie trzeba chyba jednak natychmiast sądzić, że brak tej wiary jest wynikiem uporu, jak sądzi m.in. Phillips 1999, s. 546.

${ }^{22} \mathrm{Z}$ wyraźnym nawiązaniem do proroctwa Dn 7,13-14 ukazującego wszechwładne, otrzymane od Boga, panowanie Syna Człowieczego, na co powszechnie egzegeci zwracają uwagę (por. m.in. France 2007, s. 1112-1113).

${ }^{23}$ Uczeń to ten, który nie tylko przyjmuje coś do wiadomości, lecz także wciela w życie to, czego się nauczył. Dlatego życie ucznia ma odróżniać się od świata przede wszystkim przywiązaniem do Jezusa. On ma stać się obecnie ważniejszy niż dotychczasowy kierunek życia ucznia (por. Morris 1992, s. 746). 
Teologia wynikająca $\mathrm{z}$ tekstu jest równie jednoznaczna: Jezus nie wypowiada tych słów jako człowiek, lecz jako Syn Boży, na co wskazują następujące elementy Jego posłania:

a) władza nie tylko na ziemi, lecz także w niebie;

b) uroczysta proklamacja sakramentu chrztu świętego;

c) wieczysta obecność Jezusa na ziemi mimo rychłego wstąpienia do nieba.

Wynika stąd prawda, że Jezus pozostaje jako Bóg-Emmanuel nie tylko przy swoich uczniach $(1,23)$, lecz po zmartwychwstaniu jest wywyższony, równy Ojcu i Duchowi (w. 19) i wszechobecny (w. 20b) ${ }^{24}$. Wydaje się natomiast, że wszelkiej władzy nie zyskuje On na mocy swego bóstwa, lecz dokonanego dzieła zbawienia, po poniżeniu związanym ze śmiercią krzyżową i z cierpieniem jak złoczyńca, po wyklęciu przez nieprzyjaciół i własny naród (por. Paciorek 2008, s. 779). Obecny więc Jego autorytet wynika z dokonanego dzieła i dlatego ma być przyjmowany bez wątpienia i z pełną aprobatą przez wszystkie pokolenia uczniów. Oznacza to, że bycie uczniem Jezusa musi obowiązkowo włączać posłuszeństwo autorytetowi Założyciela, lecz także Kościoła, który powołał do życia, według zapisu wersetów 16, 18. Jest całkowicie zrozumiałe, że w świadomości Pawła VI Kościół ma prawo domagać się posłuszeństwa wiary od swych wyznawców właśnie na mocy autorytetu i władzy Jezusa jako jego Twórcy oraz nadanej mu misji głoszenia słowa w imieniu Boga w Trójcy Osób. Warto także zauważyć, że misja przekazana przez Jezusa uczniom składa się z trzech fundamentalnych poziomów, uwypuklonych w w. 19: czynienie uczniami - ochrzczenie oraz utwierdzanie w nauce ${ }^{25}$. Tekst wspomina, co prawda, o ich współistnieniu i współfunkcjonowaniu, co dziś, w kontekście papieskiego dokumentu, przedstawia się nieco inaczej. Otóż główni jego adresaci są już ochrzczeni i (w zasadzie) są także uczniami, zaś obecnie pozostaje do realizacji utwierdzanie ich w nauczaniu Chrystusa i Kościoła. Nietrudno jednak wywnioskować, że zarówno pierwszy, jak i drugi składnik wiary (chrzest + wyznawanie jej prawd) mają stanowić podstawę jej utwierdzenia, czyli wzmocnienia o nowe elementy, jak te, które głoszone są przez papieża w kwestiach małżeńskich. Włożone $\mathrm{w}$ całokształt wiary uczniów Chrystusa, wkomponowują się w nią, tworząc spójną, organiczną całość, choć są niewątpliwie szczegółowe i nie należą do jej rdzenia. Niemniej jednak ich przyjęcie jest konieczne dla zachowania integralności wiary w dziedzinie moralności małżeńskiej. W ten właśnie sposób będzie czynił Kościół, ponieważ wraz ze zmartwychwstaniem Chrystusa nauczanie

\footnotetext{
${ }^{24}$ Szerzej na ten temat, por. Szpyra 2003, s. 7-19.

${ }^{25}$ Te trzy elementy bardzo przystępnie wypunktował Siemieniec 2014, s. 129.
} 
zostaje powierzone uczniom jako ściśle połączone z nauczaniem Jezusa i dokonywane w Jego imieniu (por. Kotecki 2016, s. 16-17).

Na koniec należy zauważyć, że odgrywający w całości perykopy najważniejszą bodaj rolę czasownik mathèteuō, 'nauczam', 'czynię uczniem', pojawia się w Nowym Testamencie w niewielu miejscach, lecz zawsze w kontekście przemiany postawy człowieka, polegającej na odwróceniu się od dotychczasowego sposobu myślenia i działania oraz przewartościowaniu fundamentów własnego życia (por. Schnackenburg 2002, s. 299). Czasownik ten odnosi się zarówno do takiej zmiany w postawie Żydów $(13,52 ; 27,57)^{26}$, jak i pogan $(28,19 ; \mathrm{Dz} 14,21)^{27}$, zatem każdy wezwany jest do przyjęcia treści, które mogą wręcz przestawić dotychczasowe tory jego życia. Natomiast człowiek tę siłę do przemiany odnajduje nie w sobie samym, lecz po uprzednim wezwaniu właśnie przez Pana $^{28}$. Z tej racji podsumować można niezwykle istotną rolę tekstu Mateuszowego w argumentacji encykliki:

a) wezwanie do trudnej przemiany własnego sposobu myślenia według nauczania Jezusa;

b) zaproszenie wszystkich ludzi dobrej woli do podjęcia tego trudu;

c) Jezus daje siłę do przyjęcia Jego nauki, zwłaszcza wówczas gdy pojawią się trudności w jej przyjęciu;

d) zrozumienie przez wiernych, zwłaszcza małżonków, konieczności strzeżenia czystości nauki apostolskiej przez magisterium Kościoła (por. Parzyszek 2010, s. 136-137);

e) Kościół nie może rezygnować z przepowiadania prawdy, ponieważ jest ona samą istotą jego bycia, a dialog ze światem nie zastąpi misji ${ }^{29}$.

W podsumowaniu można stwierdzić, że ,we wszystkich Ewangeliach uczeń Jezusa to ten, który idzie za Jezusem, obiera w Nim jedynego przewodnika swo-

\footnotetext{
${ }^{26}$ Mimo że - jak się wydaje ze względu na zwrot panta ta ethne, 'wszystkie narody' - w tekście Mateuszowym chodzi konkretnie o pogan, nie o Żydów (por. Siemieniec 2014, s. 129-131).

${ }^{27}$ Egzegeci zauważają silny klimaks opisu ewangelijnego od „rezerwowania” nauczania i dobroci Jezusa dla Jego rodaków przez otwarcie Go na świat pozażydowski aż po nakaz zwrócony do uczniów, by właśnie do nich ostatecznie się udać (por. Harrington 1991, s. 9, 19, 49).

${ }^{28}$ Czego przykładem jest sam autor Ewangelii w opisie swego powołania w 9,9, por. także Rengstorf 1967, s. 461.

${ }^{29}$ Mówił o tym Benedykt XVI w katechezie z dn. 11.10.2006: „Pośród wszystkich pojawiających się pokus i wszystkich prądów współczesnego życia powinniśmy zachować tożsamość naszej wiary. Oczywiście trzeba nadal wytrwale iść drogą wyrozumiałości i dialogu, jaką słusznie podjął Sobór Watykański II. Jednakże ta droga dialogu, tak bardzo potrzebna, nie powinna prowadzić do zapominania o obowiązku przemyślenia i ukazywania zawsze z jednakową mocą zasadniczych i niezbywalnych rysów naszej tożsamości chrześcijańskiej. Z drugiej strony, trzeba być świadomym tego, że nasza tożsamość domaga się siły, wyrazistości i odwagi wobec przeciwieństw świata, w którym żyjemy".
} 
jego życia, bezgranicznie i bezwarunkowo Mu ufa" (por. Kotecki 2016). Z tej racji konieczne jest podjęcie trudnej drogi wierności Bożemu nauczaniu i odejście od własnych przekonań, jeśli byłyby niezgodne z nauczaniem Kościoła.

\section{Postawa Kościoła nauczającego wobec trudności i przeciwieństw}

Powyższe stwierdzenia wynikające $\mathrm{z}$ interpretacji cytowanych urywków encykliki pozwalają na skonstatowanie ważnej przesłanki dla dalszego rozwoju myśli papieskiej: Bóg, będący miłością działającą (1 J 4,8) i Ojcem wszystkich stworzeń, szczególnie zaś ludzi (Ef 3,15), wzywa każdego człowieka do podjęcia wysiłku stawania się Jego uczniem (Mt 28,18-19).

\section{a. Świadomość głoszonej prawdy}

Znaczenie poprzedzającej uwagi podkreśla następny zapis papieża, zawarty w punkcie 18 encykliki:

Z góry da się przewidzieć, że nie wszyscy chyba łatwo przyjmą podaną naukę, skoro już podniosło się tyle głosów, które korzystając z pomocy nowoczesnych środków propagandy, sprzeciwiają się nauce Kościoła. Kościół wszakże nie dziwi się temu, że podobnie jak boski jego Założyciel, postawiony ,jest na znak, któremu sprzeciwiać się będą" (Łk 2,34b).

Co wynika z tej treści? Cztery zasadnicze punkty:

a) Kościół w całości swego nauczania dzieli los swego Założyciela jako znak sprzeciwu i osądu postaw za lub przeciw Niemu (por. Wróbel 2014, s. 13);

b) świadomość istniejących kontrowersji w dziedzinie pożycia małżeńskiego, także w łonie Kościoła;

c) świadomość, że po stronie magisterium leży prawda, której nie można przeinaczyć lub obalić;

d) świadomość, że Kościół nie może wycofać się ze swego nauczania mimo głosów sprzeciwu.

Tezy te zostają uzasadnione zapisem explicite części biblijnej relacji o przedstawieniu Jezusa w świątyni jerozolimskiej (Łk 2,22-35), zwłaszcza zaś proroctwa Symeona o boskim Dziecięciu, które stanie się znakiem sprzeciwu dla swych słuchaczy (w. 34). 
Analizę wersetu rozpocząć należy uwagą, że mamy do czynienia z proroctwem, czyli formą zapowiedzi o charakterze generalnym, dotyczącym przyszłości całego życia Tego, o którym wspomina starzec. Z wielu definicji przedłożyć można tę, według której proroctwo to proklamacja Bożej woli dotycząca zarówno teraźniejszości, jak i przyszłości ${ }^{30}$. Oznacza to, że nie chodzi wyłącznie o faktograficzną zapowiedź samego faktu, lecz o objawienie woli Bożej co do osoby, rzeczy lub wydarzenia, których wpływ na tok dziejów stanie się faktem wraz z wszelkimi tego konsekwencjami, w tym także reakcją tych, których będzie ono dotyczyć.

Chociaż całość wersetu składa się z dwóch równorzędnych członów, połączonych spójnikiem kai, 'i', można je od siebie oddzielić, zajmując się jedynie członem drugim, jak to uczynił papież, korzystając jedynie z tej właśnie części wersetu. Istotą przekazanej treści jest podział, jaki, niestety, powstanie wśród tych ludzi, którzy słuchali słów Jezusa, na tych, którzy przyjmą Jego orędzie, i tych, którzy zaoponują ${ }^{31}$. Jedni zatem potkną się o Niego, jak o kamień, inni zaś dzięki Niemu powstaną, by zostać zbawionymi. Jeśli jednak niektórzy słuchacze mają się potknąć, to muszą wpierw stać. Oznacza to, że ci, którzy są pyszni i zarozumiali, ponieważ twierdzą, że ich przekonania są mocne i zgodne z prawdą, prędzej czy później muszą upaść, ponieważ głoszona prawda Boża jest $\mathrm{z}$ gruntu inna niż ich poglądy. Taką interpretację wspomaga werset Iz 28,16, gdzie sam Bóg zapowiada położenie na Syjonie kamienia węgielnego z zapewnieniem, że kto uwierzy, nie potknie się. Upadek zwiastuje więc brak wiary ujawniający się w postawie odrzucenia orędzia Jezusowego (por. Mickiewicz 2011, s. 188-189). Ci zaś, których postawa cechuje się pokorą i otwarciem, zostaną przez Niego podniesieni do życia (por. Geldenhuys 1971, s. 120). Akcent postawiony został na odruch serca, co popiera zapis w. 35: „aby na jaw wyszły zamysły wielu serc”. Słowo, głoszone przez Jezusa, stanie się zatem wyznacznikiem wewnętrznej szczerości postawy za albo przeciw. Sens wypowiedzi starca może być zrozumiany dwojako: albo na drodze sprzeciwu argumentacyjnego, czyli z podawaniem tez przeciwnych usłyszanym, albo w życiowej postawie negującej usłyszane słowo ${ }^{32}$. Warto tę właśnie obserwację podkreślić, ponieważ, jak się wydaje, obie postawy dało się - i wciąż daje - zauważyć w reakcjach na tekst encykliki. $Z$ drugiej strony nawet bę-

${ }^{30}$ Tę prostą definicję podaje m.in. Anders 1997, s. 2-3.

${ }^{31}$ Łukasz znakomicie rozwija ów problem, poczynając od podziału słuchaczy wobec misji Jana Chrzciciela (7,29-30), poprzez misję Jezusa (4,16-30), na uczniach kończąc, już w Dziejach Apostolskich $(28,24)$. Opozycja ta ukaże wewnętrzne nastawienie słuchaczy do prawdy: odpowiedź, taka czy inna, dana Jezusowi równa się odpowiedzi danej samemu Bogu (por. Carroll 2012, s. 79).

${ }^{32} \mathrm{~W}$ ten sposób np. Godet 2004, s. 141. Odpowiednikiem tej postawy w tradycji Pawłowej jest werset Rz 10,21, gdzie autor przytacza mowę Izajasza do jego opornego ludu, który definitywnie odrzucił przesłanie akcentujące konieczność wiary bardziej niż własnych uczynków (por. Mounce 1995, s. 212). 
dąc takim znakiem, Jezus nie wycofa się z misji, do której został powołany, ponieważ od zewnętrznego poklasku i aprobaty świata ważniejsza jest prawda. Na tę interpretację wskazuje z kolei teologiczne porównanie z cytatem Iz 11,12, w którym występuje ten sam termin sèmeion, 'znak', dany od Boga, jako widzialny emblemat wskazujący właściwy kierunek marszu ${ }^{33}$. Wszystko wobec tego zależy od postawy kroczących drogą. W taki właśnie sposób chce z pewnością ukazać rolę współczesnego Kościoła Paweł VI i w kontekście wywodów papieskich mogłoby chodzić o konieczność odrzucenia własnych przekonań i poddanie się autorytetowi nauczającego Kościoła. Komentatorzy zwracają ponadto uwagę, że sens wypowiedzi Symeona nie dotyczy jedynie tych, którzy byli bezpośrednimi świadkami mów i czynów Jezusa, lecz odnosi się do każdego pokolenia słuchaczy, którzy przyjmują jedną z dwóch postaw wobec słowa: albo akceptacji (choć znów nie bez trudności), albo odrzucenia (por. m.in. Phillips 2005, s. 80). Można stwierdzić, że Chrystus staje się „znakiem sprzeciwu”, którego nie da się pominąć, jeśli pragnie się być nadal Jego uczniem (por. Krawczyk 2014, s. 263). Wierność Jego woli musi oznaczać rezygnację z własnych przekonań na rzecz tego, co On głosi. Dziś czyni to poprzez swój Kościół i jego nauczanie ${ }^{34}$.

\section{b. Szafarstwo dóbr duchowych}

Oprócz świadomości, że głoszona prawda jest fundamentem tożsamości Kościoła i warunkiem jego trwania jako wspólnoty Bożej, pojawia się również przekonanie o wartości całego bogactwa dóbr duchowych, stanowiących źródło niewyczerpanej łaski dla wszystkich wierzących. Paweł VI akcentuje to W następujący sposób w punkcie 25 encykliki:

Teraz zaś nasze orędzie w szczególny sposób kierujemy do tych Naszych Dzieci, które Bóg powołuje, by służyły $\mathrm{Mu}$ w stanie małżeńskim. Kościół bowiem nauczając o nienaruszalnych wymogach prawa Bożego, jednocześnie obwieszcza zbawienie i poprzez Sakramenty otwiera drogi Łaski, mocą której człowiek staje się nowym stworzeniem zdolnym w miłości i prawdziwej wolności odpowiedzieć

${ }^{33}$ Inni egzegeci odnoszą się do podobnych w wymowie wersetów Iz 8,18 (Izajasz i jego dzieci jako znak od Pana dla ludu) oraz 7,14 (znak dany opornemu monarsze i ludowi poprzez cudowne narodziny Dziecięcia). Oba teksty akcentują wytrwałość Boga w ukazywaniu ludowi właściwego kierunku życia, przede wszystkim odrzucenia bałwochwalstwa (por. Stein 1992, s. 117).

${ }^{34}$ Od strony egzegezy trzeba jednak jakby dopisać do interpretacji papieskiej ważne cytaty Mt 16,19, J 20,23, 1 Tes 4,8 stwierdzające autorytatywną moc działania Kościoła w imieniu Boga, co Paweł VI pomija najprawdopodobniej, przyjmując w sposób oczywisty wiarę czytelników, że ogłaszane przez Kościół dokumenty, zwłaszcza o charakterze moralnym, przyjmowane są jako rzeczywista wola Boga (1 Tes 2,13). 
na boski plan Stworzyciela i Zbawcy oraz odczuć słodycz Chrystusowego jarzma (Mt 11,30).

Uważny czytelnik natychmiast zorientuje się, że w Kościele współistnieją dwa nierozerwalne czynniki tej samej prawdy. Chodzi wpierw o jasny wykład niepodlegających dyskusji zarządzeń prawa danego przez Boga, potem zaś o rozporządzanie skarbami środków zbawienia, jakimi z kolei są: głoszone słowo oraz sakramenty, dzięki którym wierzący zyskują zdolność włączenia się w ekonomię łaski zbawienia, przemieniania swego życia i wzrostu w miłości na tyle, by w całkowitej wolności podjąć się trudu bycia wiernym normom postępowania wytyczonym przez Chrystusa. Jawi się tym samym z jednej strony trud realizacji postawionych zadań, z drugiej zaś świadomość otrzymywanej pomocy $\mathrm{w}$ postaci właściwego kierunku postępowania oraz mocy sakramentów umacniających na drodze wierności. Powodowani miłością, rzeczywiście wolni w podejmowanych decyzjach, małżonkowie stają się zdolni do całościowej i wiernej odpowiedzi na plan, jaki wobec nich ułożył Bóg, a także - tu swoisty paradoks - odczucia trudu bycia wiernymi Mu jako radości czynienia siebie godnymi partnerstwa z samym Bogiem, który przecież nieskończenie człowieka przerasta, więc z definicji nie jest jego Partnerem.

Uzasadnieniem takiej tezy ma być ewangeliczny zapis Mt 11,30, stanowiący część dłuższej wypowiedzi Jezusa, podanej w w. 28-30. Oto w w. 28 Mistrz zachęca ${ }^{35}$, by przyjść do Niego w przeróżnych, życiowych sytuacjach, w których doświadcza się trudu fizycznego, psychicznego i duchowego ${ }^{36}$ oraz obciążenia przede wszystkim z powodu znoju i ciężaru obowiązków przestrzegania prawa ${ }^{37}$. We wszystkich bowiem tych okolicznościach Bóg chce

${ }^{35}$ Grecki przysłówek deute, ‘pójdź- my/cie’ w Ewangelii Mateusza odnosi się zawsze do pobudzenia lub propozycji włączenia się w postulowaną czynność. Nie ma więc mowy o jakimkolwiek zmuszaniu, por. 4,$19 ; 21,38 ; 22,4 ; 25,34$ oraz 28,6 .

${ }^{36}$ Czasownik kopiāo oznacza tyle, co 'męczę', 'mozolę', 'zmagam się' z podkreśleniem trudu własnego, aby osiągnąć oczekiwane wyniki własnej pracy. Chodzi o trud pracy fizycznej (Joz 24, 3; Ps 126,1; Syr 11,11; 31,3-4; Iz 16,12; 46,1; 65,23; Ier 28,58; Łk 5,5; Dz 20,35; Rz 16,6; 1 Kor 4,12; Ef 4,28; 2 Tm 2,6), noszenia ciężarów (1 Bas 17,39), walki zbrojnej (1 Bas 14,31; 2 Bas 17,2; 23,10), niewolnictwa (Iz 45,14), poszukiwań (Jr 2,24), wędrowania w upale (Pwt 25,18; Iz 30,4; 57,$10 ; 63,13 ; \mathrm{J} 4,6$ ), jęczenia/krzyczenia (PS 6,7; 68,4), pracy apostolskiej (Iz 49,4; Rz 16,12; 1 Kor 15,10; 16,16; Ga 4,11; Flp 2,16; Kol 1,29; 1 Tes 5,12; 1 Tm 4,10; 5,17), zdobywania życiowej mądrości (Prz 4,12; Mdr 6,14; Syr 6,19; 24,34; 33,18; 51,27), żywienia osób nieprzydatnych lub szkodliwych (Iz 47,13.15), szeroko pojętego cierpienia (Iz 31,3; 33,24; 40,30-31; Lm 5,5; Ap 2,3), a nawet oddawania czci Bogu (Syr 43,30). W Ewangelii Mateusza występuje jeszcze tylko w 6,28 (por. paralelnie $Ł k$ 12,27) w brzmieniu przeczącym, w odniesieniu do lilii polnych wolnych od trudu (ou kopiōsin), przyozdabianych dobrocią Ojca w niebie.

37 Bardzo rzadki w Biblii greckiej czasownik fortidzō oznacza 'obarczam', 'obładowuję', 'przygniatam', 'przytłaczam ciężarami'. W Septuagincie występuje tylko w wersecie Ez 16,33, wskazując na trud, jaki podejmowali niewierni i bałwochwalczy Izraelici pragnąc przyciągnąć do siebie pogan. Chodzi więc o trud szkodliwy, niepotrzebny, nieprzynoszący żadnej duchowej 
zapewnić stosowne pokrzepienie ${ }^{38}$. Wprowadzający w nowe czasy zbawienia Jezus przynosi odpoczynek zarówno fizyczny, psychiczny, jak i duchowy tym, którzy gięli się przede wszystkim pod ciężarem legalistycznych nakazów judaizmu (por. Hauck 1965, s. 829). W dokumencie papież wyraźnie obejmuje całościowo sens wszystkich tych terminów, rozciągając je na wszelkie życiowe sytuacje, by z jednej strony dać znać, że w nich wszystkich ludzie znajdą oczekiwaną pomoc Jezusa, z drugiej jednak, by nie szukali usprawiedliwień dla siebie, gdy podejmują próby obejścia Jego nakazów i zaleceń w okolicznościach, które okazują się dla nich trudne. Kluczowy w. 29 tekstu Mateuszowego podaje zachętę do wzięcia jarzma Chrystusowego, uczenia się życia na Jego sposób, tzn. życia pokornego i podporządkowanego Bogu, by w nagrodę znaleźć pokój serca i ukojenie duszy, czyli pełną akceptację trudów podjętych dla Niego, a nawet radość z nich. Różnica między nauczaniem rabinów a Jezusowym polega na tym, że poddanie się pod jarzmo Tory oznacza akceptację przepisów prawa, które człowiek musi wykonywać wysiłkiem własnym. Jezus, zachęcając do poddania się Jego prawu, nie wspomina o przepisach, lecz o sobie, o tym, że daje siłę i wytrwałość. Nie Prawo jest więc w centrum, lecz On sam (por. Blomberg 1992, s. 194-195). W tym świetle, według zamysłu Pawła VI, poddanie się chrześcijanina prawu Jezusa oznacza moc daną przez Niego każdemu, kto zechce podjąć trud wierności prawu małżeńskiemu założonego przez Niego Kościoła. Ważna jest jednak zachęta do nauki (mathēte) od Niego. Ten proces zawsze jest dhugotrwały i nastręcza trudnośsi ${ }^{39}$, wpierw ze zrozumieniem materiału, później zaś z wcielaniem go w życie, jak w każdej szkole. Z Jego pomocą doprowadzi to jednak ostatecznie do zbawienia, czyli niewspółmiernie szczodrej zapłaty za trud pozostania wiernym Bogu. Widać więc dwie fundamentalne korzyści w porównaniu ze starotestamentową drogą nauki i przyswajania prawa: człowiek nie czyni tego własnymi tylko siłami oraz nie podporządkowuje swej wolności jedynie przepisom prawa mojżeszowego. Dobrowolne podporządkowanie się prawu Jezusa skutkuje Jego natych-

lub materialnej korzyści (por. Allen 1994, s. 241). Duchowy poziom rzeczownika odkrywa cytat Łk 11,46 wstawiający go w kontekst legalistyki judaistycznej, w ataku Jezusa na zwolenników rygorystycznego przestrzegania prawa Mojżeszowego. Niemożliwe jest uniesienie ciężaru wszystkich przepisów siłami czysto ludzkimi (por. Johnson 1991, s. 190).

${ }^{38}$ Czasownik anapauō oznacza odpoczynek natury fizycznej (Rdz 29,2; Kpł 25,2; Pwt 5,14; Est 9,17-18; Jdt 10,21; Hi 3,13.26; Syr 3,6; Mi 4,4; Iz 13,20; 14,30; Dn 12,13; Mt 26,45; Mk 6,31; 14,41; Łk 12,19), poczucie bezpieczeństwa (Rdz 49,14; Pwt 28,65; 33,20; 2 Bas 7,11; 3 Bas 5,18; 1 Par 22,9.18; 2 Ezd 19,28; Iz 27,10; 32,18; 34,17; Ier 31,11; Ez 34,14-15), uwolnienie od nieprzyjaciół (Est 9,16.22; Iz 14,1.4.7), ulgę w trudach i uwolnienie od rozczarowań (Prz 29,17; Hi 3,17; 10,26; Lm 5,5), ukojenie nerwów i niepokoju (1 Bas 16,16; Ha 3,16), pokrzepienie duchowe (1 Kor 16,18; 2 Kor 7,13; Flm 7.20). a wreszcie przejście w stan śmierci (Syr 22,11; 47,23) i pokój pośmiertny (Ap 6,11;14,13).

${ }^{39} \mathrm{~W}$ Starym Testamencie jako nakaz dany do Boga lub stwierdzenie uczenia się mądrości, por. m.in. Pwt 4,10; 5,1; 14,23; 17,19; 31,12-13; Ps 118,7.71.73; Mdr 6,1.9; Syr 16,24; Iz 26,9. 
miastowym wsparciem oraz nagrodą życia wiecznego, co nieporównywalnie wywyższa wartość Jezusowej zachęty do wierności Mu. Wobec tego owocem wierności nauczaniu encykliki będzie pomoc samego Pana w wypełnieniu jej zaleceń, a nagroda za wierność będzie sowita. Ostatni w. 30 mowy Jezusowej podkreśla wartość (chrēstos, dosł. 'godny', 'rzetelny') ${ }^{40}$ Jego jarzma ${ }^{41}$, stanowiącego podstawę wszelkich cnót człowieka. Paradoksalnie więc ktoś, kto poddaje się pod Boże jarzmo, zostaje uwolniony od tego, które nakłada człowiekowi człowiek ${ }^{42}$ lub jego własne przekonania ${ }^{43}$. Na koniec warto podać argument najważniejszy, wynikający z w. 29-30: przyjęcie jarzma Jezusowego to inaczej naśladowanie Jego samego, ponieważ nikt tak, jak On, nie potrafił ucieleśnić w swym życiu woli Bożej, wynikającej z przykazań. Zachęta, jakkolwiek całkowicie dobrowolna, do naśladowania Go jest w istocie moralną koniecznością, jeśli ktokolwiek chce prawdziwie nazywać się Jego uczniem (por. Paciorek 2004, s. 484-485). W związku z tym włączenie nauczania papieskiego w ciąg życia chrześcijanina, jako przedłużenia nauczania samego Jezusa, musi zostać poddane tym samym wymogom moralnym.

\section{c. Nauczanie o prawie naturalnym}

Jeden z cytowanych passusów biblijnych stał się podstawą wyrażenia teologicznej tezy o istnieniu i funkcjonowaniu prawa naturalnego. Paweł VI pisał w punkcie 4: „Prawo bowiem naturalne jest również wyrazem woli Bożej i jego wierne przestrzeganie jest ludziom konieczne do zbawienia".

Nieco szerszy kontekst tematyczny omawianego punktu został już przedstawiony przy okazji omówienia perykopy Mt 28,18-19, obecnej również w tym punkcie dokumentu papieskiego. Chodzi tutaj o kompetencje Urzędu Nauczycielskiego Kościoła w zakresie możliwości autorytatywnego wyłożenia zasad prawa naturalnego. Trzeba jednak obecnie doprecyzować definicję

${ }^{40}$ Bóg jako chrēstos, por. Ps 24,8; 33,9; 68,17; 85,5; 99,5; 105,1; 106,1; 108,21; 118,68; 135,1; 144,9; Na 1,7; Ier 40,11; Dn 3,89; 1 P 2,3.

${ }^{41}$ Dzygos jako ciężkie jarzmo pracy, niewoli i powinności, nakładane przez wrogów i ciemiężycieli, por. m.in. 2 Krn 10,4.9-11.14; 1 Mch 8,18.31; 13,41; Syr 28,19-20; Iz 47,6; Ier 34,8.

${ }^{42}$ Bóg uwalniający od takiego ciężaru, por. Kpł 26,13; Iz 9,3; 10,27; 14,5.25. Można by powiedzieć, że przejrzystość nauczania Kościoła sprawia, że oszukiwani ludzie chętniej poddają się ciężarowi wierności Bogu.

${ }^{43}$ Warto podkreślić szczególnie wymowę tekstu So 3,9 łączącego motywy: oczyszczenia mowy człowieka, dokonanego przez Boga i zarazem przeznaczenia ludu do poddania się Jego jarzmu. Bóg poddający pod swe jarzmo staje się zarazem Bogiem ocalenia od jarzma fałszywych bożków (por. Barker 1999, s. 488-489). W ten sposób przejrzystość nauczania Kościoła sprawia, że oszukiwani przez własne przekonania, poglądy lub nawet uprzedzenia ludzie chętniej poddają się ciężarowi wierności Bogu. 
prawa naturalnego, by uniknąć jakiejkolwiek wieloznaczności. Po ukazaniu się encykliki w komentarzu krakowskich teologów moralistów pod przewodnictwem kard. Wojtyły, ówczesnego metropolity Krakowa, napisano: „Papieże przez prawo naturalne rozumieją obiektywny porządek moralny wypisany w rozumnej naturze człowieka, niezależny od prawa pozytywnego ustanowionego przez władzę państwową, stały i niezmienny, obejmujący wszystkich ludzi, zawierający nie tylko najogólniejsze idee i zasady moralne, ale też szczegółowe normy postępowania"44. Egzemplifikacją powyższego nauczania jest podany werset Mt 7,21, stanowiący autorski zapis słów Jezusa: „Nie każdy, który Mi mówi: «Panie, Panie!», wejdzie do królestwa niebieskiego, lecz ten, kto spełnia wolę mojego Ojca, który jest w niebie". W kontekście wyżej przytoczonej tezy dokumentu papieskiego należy rozumieć tę wypowiedź Pana jako niezależną od znajomości lub nieznajomości zarówno prawa mojżeszowego, jak i całokształtu wiary chrześcijańskiej. Wola Boga bowiem jest wypełniana nawet przez niewierzących, jeśli chcą oni żyć uczciwie i według praw sumienia ${ }^{45}$.

Wzmiankowany werset znajduje się w bliższym kontekście w. 15-23 ostrzegających przed fałszywymi nauczycielami, których należy się wystrzegać; ich działalność można poznawać po zdecydowanie negatywnych skutkach (w. 15-20). Werset 21 ukazuje fałsz w postawie tych ludzi, którzy podają wiernym niewłaściwe nauki, lecz by zdobyć ich uznanie, oficjalnie zwracają się do Boga jako swojego Pana. Wspominają swe zasługi, zwłaszcza spektakularne cuda, usuwanie złych duchów i wyjątkowej jakości nauczanie (w. 22). Zostaną jednak całkiem odrzuceni przez Boga z powodu niegodziwości, którą próbowali zatuszować, a która z uwagi na mądrość Boga wyjdzie całkowicie na jaw (w. 23$)^{46}$.

Tekst biblijny ma wyraźny charakter polemiczny. Warto podkreślić, że podwójny zwrot „Panie, Panie” występuje najczęściej w cytowanych przez Jezusa słowach uczniów, gdy kierują się oni do Niego, jak w w. 22 oraz 25,11, chcąc pójść za Nim lub prosić Go o możliwość zbawienia. We wszystkich tych przypadkach ukazują owo ogólne pragnienie kontynuowania Jego drogi, wzywając zarazem Jego pomocy. Tymczasem nie wystarczy jedynie hipotetycznie pragnąć lub nawet modlić się do Niego ${ }^{47}$, lecz trzeba jeszcze z prze-

${ }^{44}$ Por. Notificationes e curia Metropolitana Cracoviensi, nr 1-4 A.D. 1969, s. 86.

45 Jak tego uczy Konstytucja o Kościele Lumen gentium 16: „Nie odmawia Opatrzność Boża koniecznej do zbawienia pomocy takim, którzy bez własnej winy w ogóle nie doszli jeszcze do wyraźnego poznania Boga, a usiłują nie bez łaski Bożej, wieść uczciwe życie. Cokolwiek bowiem znajduje się w nich z dobra i prawdy, Kościół traktuje jako przygotowanie do Ewangelii i jako dane im przez Tego, który każdego człowieka oświeca, aby ostatecznie posiadł życie”.

${ }^{46}$ Bardzo dobrze strukturę ostrzeżenia Jezusa ukazał Paciorek 2004, s. 320.

${ }^{47}$ Jako modlitwa i zwrot bezpośredni do Boga, por. także Pwt 3,24; 9,26; 3 Bas 8,53; 1 Par 17,24; Est 4,17b; 2 Mch 1,24; Ps 68,7; 108,21; 129,3; 139,8; 140,8; Am 7,2.5; Ier 28,62; Ez 21,5. 
konaniem przyjąć Jego wolę i okazać jej całkowite posłuszeństwo. Wówczas dopiero wyznanie Go jako Pana sprawi, że stanie się On Panem całego ludzkiego życia. Dla innych z kolei wyznanie Go jest sposobem oddalenia od siebie ewentualnych zarzutów lub uzewnętrznieniem chęci wykorzystania Go dla własnych celów, manipulowania wiarą i postawami innych ludzi albo przyznawania się do Niego tylko w przypadku, gdy czyni On wszystko po myśli człowieka. Takich postaw Jezus nie może zaakceptować, bo to nie Bóg ma być na usługi człowieka. To On ma wyłączne prawo do ludzkiego serca i poprzez realizację Jego przykazań człowiek dochodzi do obiecanego zbawienia ${ }^{48}$. Zatem dopiero wówczas, gdy modlitwa i wyznawanie wiary łączy się z praktyką całego życia, można wejść do królestwa niebieskiego ${ }^{49}$. Postawa ta wyraża się zwłaszcza w całkowitej zgodzie z deklarowanymi na zewnątrz zasadami wiary. Bóg nie znosi hipokryzji i swoistej schizofrenii religijnej, nie toleruje publicznego wyznawania wiary, najczęściej w postaci głośnej modlitwy, które nie idzie w parze z uczynkami (por. Blomberg 1992, s. 133; France 2007, s. 294). Wynikać to może już to $\mathrm{z}$ braku walki z własnymi słabościami, już to - co gorsze $-\mathrm{z}$ tworzonymi przez siebie przekonaniami niezgodnymi $\mathrm{z}$ nauczaniem Jezusa, a potem Kościoła.

Pisząc Humane vitae, Paweł VI miał głęboką świadomość, że trud wymagań, jakie stawia przed wyznawcami Chrystusa, spowoduje liczne kontestacje i zarzuty, nawet w gronie teologów, moralistów i duszpasterzy. Używając tego tekstu biblijnego, mógł się - wbrew swej woli - narazić na zarzut zmuszania wiernych do posłuszeństwa $\mathrm{z}$ wykorzystaniem słowa Bożego, by unikać dyskusji i wyrażania poglądów niezgodnych z nauczaniem oficjalnym magisterium. Jeśli zaś wypowiedź papieska pojawia się w kontekście prawa naturalnego, czyni to wszystkich ludzi odpowiedzialnymi przed Bogiem za ich postępowanie, także w kwestiach życia małżeńskiego, niezależnie od przyjęcia czy odrzucenia wiary chrześcijańskiej.

${ }^{48}$ Możliwe, że właśnie dlatego pojawia się w wersecie zapis „Panie, Panie”, nie zaś „Ojcze”, zwrot ulubiony przez Jezusa, gdy nauczał zwłaszcza o dobroci Boga wobec ludzi (por. Senior 1998, s. 133).

49 Jezus zaś jawi się jako Sędzia sądu ostatecznego (por. Paciorek 2004, s. 324). 
THE BIBLICAL FOUNDATIONS OF THE ENCYCLICAL HUMANAE VITAE

\begin{abstract}
The problems presented in Humanae vitae have become the object of harsh disagreement even in the Church some fifty years after the encyclical's publication. The dispute has been extended to the possibility that the Magisterium of the Church should give lay people some direction in their lives. Moreover, the disagreement has also concerned the boundaries of freedom of choice for a person who wants to live by their accepted rules. The document in question is a testimony to the pope's responsibility to Christ and the world for the immutability of truths taught by the Church. It is also a courageous testament to the issue of sexual intercourse of spouses in the age of a general slackening or negation of morals which guard the indissolubility of marriage. It comes as no surprise that the pope referred to the few - yet important - biblical texts in order to justify the rightness and significance of the undertaken issues, as well as their permanence in the lives of particular people of faith. The present paper attempts to prove that the choice of the biblical texts was not random; moreover, this paper fully justifies the truths touched upon in the encyclical which are difficult to accept in the contemporary mentality. Due to the limited character of this research, it will only deal with those quotations that show the depth of the encyclical's anchorage in the truths resulting from the infallible Scripture, which has a strong bearing on the justification of the encyclical's sanctity in the moral issues of widely understood human sexuality in the light of the Church teachings.
\end{abstract}

Keywords: Teachings of the Church; morality; Bible; Humanae vitae; Pope Paul VI; papal encyclicals

Słowa kluczowe: nauczanie Kościoła; moralność; Biblia; Humanae vitae; Paweł VI; encykliki papieskie

\title{
BIBLIOGRAFIA
}

Allen L.C. (1004), Ezekiel 1-19, Word Biblical Commentary 28, Dallas.

Anders M. (1997), What You Need to Know About Bible Prophecy in 12 Lessons, Nashville-Dallas-Mexico City-Rio de Janeiro.

Bailly A. (1963), Le dictionnaire grec-français, Paris.

Barker K.L. (1999), W. Bailey, Micah - Nahum - Habakkuk - Zephaniah. An Exegetical and Theological Exposition of Holy Scripture, The New American Commentary 20, Nashville.

Biesaga T. (2011), Personalizm etyczny K. Wojtyty, w: Encyklopedia filozofii polskiej, t. 2, red. A. Maryniarczyk, Lublin.

Blomberg C.L. (1992), Matthew: An Exegetical and Theological Exposition of Holy Scripture, The New American Commentary 22, Nashville. 
Boring M.E., Craddock F.B. (2009), The People's New Testament Commentary, Louisville.

Carroll J.T. (2012), Luke: A Commentary, The New Testament Library, Louisville.

Foulkes F. (1989), The Letter of Paul to the Ephesians: An Introduction and Commentary, Tyndale New Testament Commentaries, Grand Rapids-Cambridge.

Fowl S.E. (2012), Ephesians: A Commentary, The New Testament Library, Louisville.

France R.T. (2007), The Gospel of Matthew, The New International Commentary on the New Testament, Grand Rapids.

Geldenhuys N. (1971), The Gospel of Luke, The New International Commentary on the New Testament, Grand Rapids.

Gilde R., Mark J., Warring A. red. (2017), Europe's 1968: Voices of Revolt, Oxford.

Godet F.L. (2004), A Commentary on the Gospel of St. Luke, Eugene.

Goniszewski P. (2015), Egzegeza Mt 28,16-20 z hebrajskiej wersji Ewangelii wg św. Mateusza (shemtob), „Studia Koszalińsko-Kołobrzeskie” 22, s. 11-19.

Haręzga S. (2007), Formuła „Bóg jest miłościa” w $1 \mathrm{~J}$ 4, 8. 16 i jej recepcja z pierwszej encyklice Benedykta XVI, „Collectanea Theologica” 77, nr 3, s. 63-79.

Harrington D.J. (1991), The Gospel of Matthew, Sacra Pagina, t. 1, Collegeville.

Hauck F. (1965), art. ко́лоร, колí́ $\omega$, Theological Dictionary of the New Testament t. 3, s. 827-830.

Hoehner H.W. (2002), Ephesians: An Exegetical Commentary, Grand Rapids.

Johnson T.F. (1993), 1, 2 and 3 John, New International Biblical Commentary, Peabody.

Johnson L.T. (1991), The Gospel of Luke, Sacra Pagina, t. 3, Collegeville.

Kotecki D. (2016), Chrzest „w imię Ojca i Syna, i Ducha Świętego” (Mt 28,19) w ujęciu biblijnym: od egzegezy do aktualizacji, „Człowiek i Teologia” t. 35, nr 3, s. 11-37.

Krajewski W. (2006), Etyka jako filozofia pierwsza. Doświadczenie normatywnej mocy prawdy źródtem i podstawa etyki, Lublin.

Krawczyk R. (2014), Dziękczynny hymn Symeona (Łk 2,25-35), „Studia Redemptorystowskie” 12, s. $256-264$.

Kruse C.G. (2000), The Letters of John, The Pillar New Testament Commentary, Grand Rapids.

Langkammer H. (2001), List do Efezjan, Pismo Święte Nowego Testamentu, Lublin.

Léon-Dufour X. (1993), Lecture de l'Évangile selon Jean : Les adieux du Seigneur (chapîtres 13$-17)$, t. 3, Paris.

Mędala S. (2008), Ewangelia wedtug świętego Jana, rozdziaty 13-21, Nowy Komentarz Biblijny, Nowy Testament, t. IV/2, Częstochowa.

Mickiewicz F. (2011), Ewangelia wedtug świętego Eukasza, rozdziały 1-11, Nowy Komentarz Biblijny, Nowy Testament, t. III/1, Częstochowa.

Morris L. (1992), The Gospel According to Matthew, The Pillar New Testament Commentary, Grand Rapids.

Mounce R.H. (1995), Romans: An Exegetical and Theological Exposition of Holy Scripture, The New American Commentary 27, Nashville.

Notificationes e curia Metropolitana Cracoviensi, nr 1-4 A.D. 1969, s. 71-105.

Paciorek A. (2004), Ewangelia wedtug świętego Mateusza, rozdziaty 1-13, Nowy Komentarz Biblijny, Nowy Testament, t. 1, cz. 1, Częstochowa.

Paciorek A. (2008), Ewangelia wedlug świętego Mateusza, rozdziały 14-28, Nowy Komentarz Biblijny, Nowy Testament, t. 1, cz. 2, Częstochowa.

Parzyszek C. (2010), Treść pojęcia „,nowa ewangelizacja” wedtug Jana Pawła II, „Kultura - Media - Teologia" 2, s. 135-151.

Phillips J. (2005), Exploring the Gospel of Luke: An Expository Commentary, John Phillips Commentary Series, Grand Rapids.

Phillips J. (1999), Exploring the Gospel of Matthew: An Expository Commentary, John Phillips Commentary Series, Grand Rapids.

Rengstorf K.H. (1967), art. $\mu \alpha \theta \eta \tau \varepsilon v ́ \omega$, Theological Dictionary of the New Testament, t. 4, s. 461.

Rensberger D. (1997), 1, 2, \& 3 John, Abingdon New Testament Commentaries, Nashville. 
Schnackenburg R. (2002), The Gospel of Matthew, Grand Rapids-Cambridge.

Senior D. (1998), Matthew, Abingdon New Testament Commentaries, Nashville.

Siemieniec T. (2014), Antyewangelizacja i ewangelizacja w świetle Mt 28, 11-20, „Kieleckie Studia Teologiczne" 13, s. 119-134.

Stanley J. (2013), Rebuilding the Church: Pope Francis and After, b.m.

Stein R.H. (1992), Luke: An Exegetical and Theological Exposition of Holy Scripture, The New American Commentary 24, Nashville.

Stott J.R.W. (1995), The Letters of John, Tyndale New Testament Commentaries, Leicester-Grand Rapids.

Struzik Z. (2010), ,,Rodzina Bogiem silna moca swego narodu”. Nauczanie o rodzinie kard. S. Wyszyńskiego, ,Kultura - Media - Teologia” 3, s. 105-119.

Szpyra S. (2003), Nakazy misyjne Chrystusa (Mt 28,19), „Nurt SVD” 37/4, s. 7-19.

Wróbel M.S. (2014), „A Twoja duszę miecz przeniknie” (Łk 2, 35): wspólnota losu Maryi i Jezusa, „Salvatoris Mater” 14/1/4, s. 11-20.

JANUSz NAWRot - kapłan archidiecezji poznańskiej. Urodzony w Międzychodzie, woj. wielkopolskie. W latach 1979-1985 studia w Arcybiskupim Seminarium Duchownym w Poznaniu. Studia specjalistyczne z dziedziny biblistyki w Instytucie Katolickim w Paryżu (1988-1992). Obecnie profesor nadzwyczajny w Zakładzie Nauk Biblijnych Wydziału Teologicznego Uniwersytetu im. Adama Mickiewicza w Poznaniu (tytuł: 2013). Autor licznych artykułów i 7 książek naukowych z dziedziny biblistyki. 